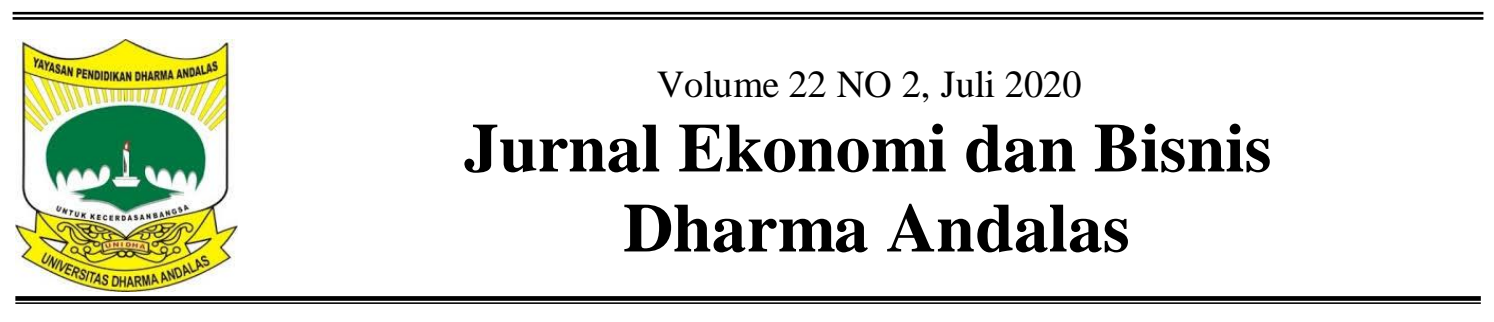

\title{
Pengaruh Struktur Modal Terhadap Laba Pada PT. Telekomunikasi Indonesia (Persero) TBK
}

\author{
Jaka Wijaya ${ }^{1}$, Aliah Pratiwi ${ }^{2}$ \\ Sekolah Tinggi Ilmu Ekonomi (STIE) Bima ${ }^{1,2}$ \\ Email: Wijaya17april@gmail.com ${ }^{1}$ \\ Email: aliahpratiwi@ymail.com ${ }^{2}$
}

\begin{abstract}
This study aims to determine the effect of capital structure on earnings at PT. Telekomunikasi Indonesia (Persero) Tbk. The independent variable in this study is the capital structure measured using DER and the dependent variable in this study is the company's profit. This research uses associative research methods. The population used in this study were all PT. Telekomunikasi Indonesia Tbk for 13 years from 2006 with the sampling technique used was purposive sampling, the sample used was 6 years from 2013-2018. The data analysis technique used is simple linear regression with SPSS 16 for windows. The results of the analysis of DER data (ratio of debt to equity) for 6 years from the study data showed fluctuating percentages. Based on the results of the statistical tests conducted in this study, the results obtained are that the Capital Structure has no effect and is not significant to Profit. This can be seen from the results of the t test conducted tcount obtained 1.661 <ttable 2.776, and the sig value 0.172> 0.05 , it can be concluded that the Capital Structure variable has no effect and is not significant on Profit.
\end{abstract}

Keywords : capital structure, profit, DER

\begin{abstract}
ABSTRAK
Penelitian ini bertujuan untuk mengetahui pengaruh struktur modal terhadap laba pada PT. Telekomunikasi Indonesia (Persero) Tbk. Variabel bebas dalam penelitian ini yaitu struktur modal yang diukur dengan menggunakan DER dan yang menjadi variabel terikat dalam penelitian ini adalah laba perusahaan. Penelitian ini menggunakan metode penelitian asosiatif. Populasi yang digunakan dalam penelitian ini yaitu seluruh laporan keuangan konsolidasi PT. Telekomunikasi Indonesia Tbk selama 13 tahun dari tahun 2006 dengan Teknik sampling yang digunakan yaitu purposive sampling, sampel yang digunakan yaitu 6 tahun dari tahun 2013-2018. Teknik analisis data yang digunakan adalah regresi linier sederhana dengan program SPSS 16 for windows. Hasil analisis data DER (debt to equity ratio) selama 6 tahun data penelitian menunjukkan persentase yang berflutuasi. Berdasarkan hasil uji statistik yang dilakukan dalam penelitian ini diperoleh hasil yaitu Struktur Modal tidak berpengaruh dan tidak signifikan terhadap Laba. Hal ini terlihat dari hasil uji $\mathrm{t}$ yang dilakukan diperoleh nilai $\mathrm{t}_{\text {hitung }} 1,661<\mathrm{t}_{\text {tabel }}$ 2,776, dan nilai sig 0,172>0,05, maka dapat disimpulkan bahwa variabel Struktur Modal tidak berpengaruh dan tidak signifikan terhadap Laba.
\end{abstract}

Kata Kunci : struktur modal, laba, DER

\section{PENDAHULUAN}

Di era globalisasi seperti saat ini, aktifitas di dunia bisnis dihadapkan dengan persaingan yang sangat ketat, karena inilah sebuah perusahaan di tuntut untuk terus berkembang dengan cara meningkatkan kapasitas produksi perusahaan dan perluasan usaha di dalam 
memproduksi beranekaragam jenis produksi yang beragam. Untuk mengembangkan suatu perusahaan agar menjadi lebih baik lagi, perusahaan pasti membutuhkan dana yang cukup besar, yaitu dengan cara melakukan pinjaman kepada pihak ketiga. Hal ini dilakukan agar perusahaan dapat mengembangkan usaha yang di miliki.

Sebuah perusahaan yang sedang mengembangkan usaha bisnisnya pasti akan membutuhkan dan mengeluarkan biaya yang cukup besar, baik itu dana yang berasal dari modal sendiri ataupun hutang. Dalam hal ini strategi bisnis sangatlah penting untuk dimiliki oleh suatu perusahan contohnya strategi yang berkaitan dengan sumber dana karena komposisi hutang dan modal sendiri yang optimal akan memaksimalkan nilai perusahaan serta menghindarkan perusahaan dari kesulitan keuangan di masa yang akan datang.

Untuk memenuhi kebutuhan dana perusahaan, ada 2 alternatif pemenuhan modal yang bisa di pilih oleh perusahaan yaitu dengan menggunakan modal sendiri atau menggunakan modal pinjaman. Modal sendiri bisa berasal dari modal saham, laba ditahan atau dana cadangan. Tetapi apabila dana dari modal sendiri tersebut masih mengalami kekurangan maka perusahaan perlu menggunakan alternatif lain yaitu menggunakan modal pinjaman dari pihak luar perusahaan yaitu hutang kepada pihak lain. Apabila perusahaan memutuskan untuk menggunakan pinjaman (hutang), maka perusahaan harus membandingkan tingkat bunga pinjaman yang di keluarkan dengan hasil yang dapat di peroleh dari penggunaan dana pinjaman yang dilakukan. Sebaliknya, apabila perusahaan memutuskan menggunakan pendanaan dengan modal sendiri maka perusahaan harus memperhitungkan tingkat pemulihan atas modal yang telah di tanam.
Untuk memenuhi kebutuhan dana perusahaan, perusahaan diharuskan memikirkan alternatif-alternatif pendanaan keuangan yang dirasa cukup efisien untuk di terapkan di perusahaan. Pendanaan yang efisien akan terjadi bila suatu perusahaan mempunyai struktur modal yang optimal. Struktur modal yang optimal menurut Martono (2004:68) dapat diartian sebagai struktur modal yang meminimalkan biaya penggunaan modal keseluruhan atau biaya modal rata-rata, sehingga memaksimalkan nilai perusahaan. Struktur modal adalah perimbangan jumlah hutang panjang yang bersifat permanen atau perbandingan antara hutang jangka panjang dan modal sendiri yang digunakan perusahaan (Sartoto 2010:225).

Nilai suatu perusahaan selalu dikaitkan dengan struktur modal yang dimiliki, karena struktur modal memiliki pengaruh yang besar terhadap tingkat laba yang dapat diperoleh perusahaan. Alasannya karena semakin baik struktur modal yang dimiliki perusahaan maka semakin besar pula nilai atau tingkat laba yang diperoleh, sebaliknya semakin buruk struktur modal yang dimiliki perusahaan makan laba yang akan diperoleh perusahaan juga akan semakin kecil atau bisa terjadi kerugian.

Dalam menjalankan suatu usaha, setiap perusahaan pasti menginginkan laba dari setiap aktivitas produksi yang dilakukan. Memperoleh laba yang tinggi sudah tentu menjadi tujuan utama yang ingin di capai oleh setiap perusahaan. Ukuran kinerja keuangan suatu perusahaan juga dapat dilihat dari laba yang di peroleh. Kinerja keuangan perusahaan yang baik bisa diukur melalui laba yang didapat setiap tahunnya lebih-lebih apabila laba yang didapat setiap tahunnya terus mengalami peningkatan.

Menurut Baridwan (2010:29), Laba ialah peningkatan aktiva bersih 
yang bersumber atas transaksi sampingan maupun transaksi yang sedikit kemungkinan terjadi pada suatu badan usaha, serta dari seluruh transaksi ataupun peristiwa lain yang mempengaruhi badan usaha selama satu periode kecuali yang muncul dari revenue ataupun investasi oleh pemilik.

$$
\text { Perusahaan menggunakan }
$$

struktur modal sebagai target struktur laba yang perusahaan inginkan guna mencapai tingkat laba perusahaan yang diharapkan untuk periode mendatang, dengan memiliki struktur modal yang ideal diharapkan bisa pula mengoptimalkan laba yang diterima perusahaan.

Untuk melihat pengaruh struktur modal terhadap laba perusahaan ada beberapa penelitian terdahulu yang bisa kita jadikan acuan, diantaranya penelitian yang dilakukan oleh Novita dan Sofie (2015) menyatakan bahwa struktur modal memiliki pengaruh negatif signifikan terhadap profitabilitas, sedangkan hasil penelitian Astivasari dan Siswanto (2018) menyatakan bahwa Struktur modal berpengaruh positif signifikan terhadap profitabilitas. Hal yang berbeda dikemukakan oleh Dira dan Astika (2014) menyatakan bahwa struktur modal tidak berpengaruh terhadap kualitas laba.

PT. Telekomunikasi Indonesia, ialah perusahaan yang berjalan dibagian informasi dan komunikasi serta penyedia jasa dan jaringan telekomunikasi secara lengkap di Indonesia. Sebagai perusahaan jasa PT. Telekomunikasi Indonesia Tbk pasti memerlukan sumber dana dalam mengelola usahanya. Perusahaan bisa memperoleh sumber dana dari modal pinjaman dan modal sendiri. Penggunaan dana dengan baik akan mempengaruhi perolehan laba perusahaan. Dalam 6 tahun terakhir laba perusahaan PT. Telkom terus mengalami fluktuatif. Hal itu terlihat dari tabel dibawah ini :
Tabel 1

Laba PT. Telekomunikasi Indonesia (persero) Tbk (dalam miliaran rupiah)

\begin{tabular}{cc}
\hline Tahun & Laba \\
\hline 2013 & 20.290 \\
2014 & 21.446 \\
2015 & 23.317 \\
2016 & 29.172 \\
2017 & 32.701 \\
2018 & 26.979 \\
\hline
\end{tabular}

sumber : data sekunder di olah

Dari tabel 1 diatas dapat terlihat bahwa laba perusahaan selama 6 tahun itu berfluktuatif. Terlihat bahwa pada tahun 2013 laba perusahaan yaitu sebesar Rp 20,2 Triliun. Kemudian mengalami peningkatan pada tahun 2014 menjadi Rp 21,4 Triliun. Selanjutnya pada tahun 2015 kembali mengalami peningkatan hampir 2 triliun rupiah menjadi Rp 23,3. Hal yang sama terjadi pada tahun 2016 dan 2017 juga mengalami peningkatan dari $\mathrm{Rp} 32,7$ triliun menjadi Rp 32,7 triliun. Namun pada tahun 2018 laba perusahaan mengalami penurunan dari tahun sebelumnya menjadi $\mathrm{Rp} 26,9$ triliun. Penurunan laba perusahaan disebabkan karena meningkatnya beban operasional, biaya pemeliharaan dan jasa telekomunikasi, beban penyusutan dan amortisasi, beban karyawan, beban penyusutan, dan beban interkoneksi perseroan serta beban umum dan administrasi perusahaan.

Pentingnya struktur modal dalam pelaksanaan kegiatan operasional perusahaan mengharuskan perusahaan untuk tetap memperhatikan struktur modal yang dimiliki. Alasannya karena struktur modal akan berpengaruh langsung terhadap laba atau profitabilitas yang akan di capai perusahaan. Dengan struktur modal yang baik akan memudahkan perusahaan untuk 
menganalisis penggunaan hutang atau pinjaman terhadap tingkat profitabilitas agar dapat digunakan dalam proses pengambilan keputusan perusahaan.

Perusahaan yang memiliki nilai laba atau profitabilitas yang tinggi akan menjadikan perusahaan tersebut memiliki nilai yang baik dalam perusahaan. Nilai perusahaan juga dapat ditentukan oleh harga saham yang tinggi, untuk memperoleh nilai saham yang tinggi maka perusahaan harus tetap meningkatkan nilai perusahaan dengan meningkatkan nilai laba atau profitabilitas yang dimiliki. Oleh karena itu, untuk meningkatkan profitabilitas atau laba maka perusahaan harus berupaya untuk memaksimalkan struktur modal yang dimiliki. Struktur modal yang baik atau optimal akan memberikan pengaruh yang baik terhadap perolehan laba perusahaan.

Khadijah (2012) melakukan penelitian yang bertujuan untuk mengetahui pengaruh struktur modal terhadap nilai perusahaan pada PT Semen Tonasa. Data dikumpulkan melalui observasi, wawancara dan dokumentasi. Analisis data yang digunakan adalah analisis struktur modal, analisis nilai perusahaan dan analisis regresi sederhana yang menunjukkan pengaruh struktur modal terhadap nilai dalam hal ini PER berpengaruh positif.

Berdasarkan beberapa hasil penelitian terdahulu yang sudah di jelaskan diatas dapat disimpulkan bahwa pengaruh struktur modal terhadap laba menimbulkan dampak positif bagi perusahaan. Hal ini juga sesuai dengan teori struktur modal yang pernah dikemukakan oleh Modigliani-Miller (Brigham dan Houston, 2001:31), “apabila posisi struktur modal berada diatas target struktur modal optimalnya, maka setiap pengurangan modal pinjaman akan meningkatkan nilai perusahaan".
Dengan adanya fenomena yang terjadi di perusahaan di atas, peneliti tertarik untuk melakukan penelitian tentang pengaruh struktur modal terhadap laba perusahaan. Berdasarkan latar belakang diatas, maka rumusan masalah dalam penelitian ini adalah apakah struktur modal berpengaruh terhadap laba PT. Telekomunikasi Indonesia Tbk.? Adapun tujuan yang ingin dicapai dalam penelitian ini yaitu untuk mengetahui ada tidaknya pengaruh yang signifikan struktur modal terhadap laba pada PT. Telekomunikasi Indonesia Tbk.

\section{METODE PENELITIAN}

Jenis penelitian ini termasuk penelitian asosiatif. Penelitian asosiatif merupakan penelitian yang bertujuan untuk mengetahui hubungan dua variabel atau lebih. Dalam penelitian ini maka akan dapat dibangun suatu teori yang dapat berfungsi untuk menjelaskan, meramalkan dan menontrol suatu gejala (Sugiyono, 2016:21). Pada penelitian ini, metode asosiatif digunakan untuk menjelaskan tentang pengaruh struktur modal terhadap laba pada PT. Telekomunikasi Indonesia (Persero) Tbk. Oleh karena itu maka yang menjadi variabel bebas $(\mathrm{X})$ dalam penelitian ini adalah struktur modal dan yang menjadi variabel terikat $(\mathrm{Y})$ dalam penelitian ini adalah laba.

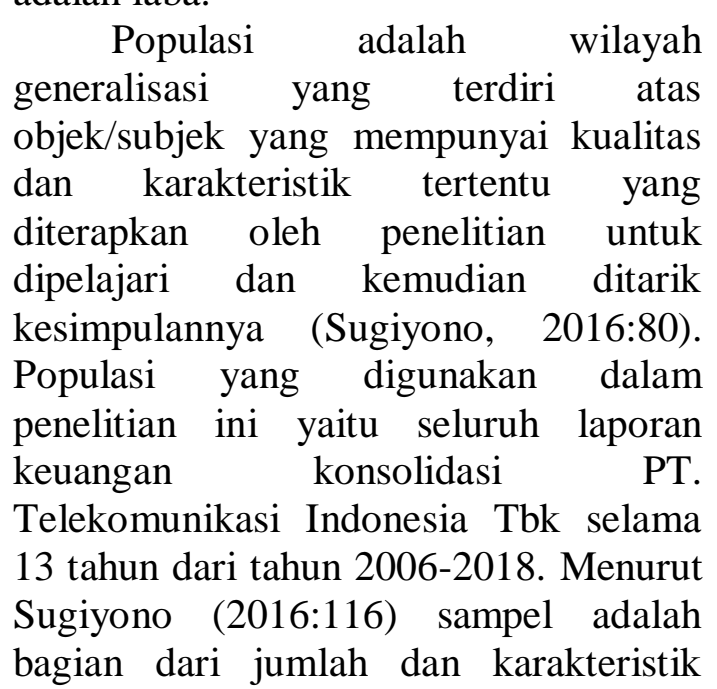


yang dimiliki populasi tersebut. Sampel dari penelitian ini yaitu data laporan keuangan 6 (Enam) tahun terakhir pada PT. Telekomunikasi Indonesia Tbk dari tahun 2013-2018. Adapun teknik pengambilan sampel yang digunakan dalam penelitian ini yakni: purposive sampling. Menurut sugiyono (2001:61), purposive sampling adalah teknik penentuan sampel dengan pertimbangan tertentu. Sampling yang digunakan dalam penelitian ini adalah purposive sampling dengan kriteria ketersediaan data, dan sampel 6 tahun sudah mewakili populasi yang ada untuk kebutuhan penelitian.

Instrumen penelitian adalah suatu alat yang di gunakan untuk mengukur fenomena alam maupun sosial yang di amati sugiyono (2008:119). Adapun instrumen yang digunakan dalam penelitian ini yaitu daftar tabel, berupa data laporan keuangan terdiri atas laporan posisi keuangan dan laba rugi.

Teknik pengumpulan data yang digunakan dalam penelitian ini adalah studi pustaka dan dokumentasi. Dokumentasi merupakan suatu cara yang digunakan untuk memperoleh data dan informasi dalam bentuk buku, arsip, dokumen, tulisan angka dan gambar yang berupa laporan serta keterangan yang dapat mendukung penelitian (sugiyono, 2015:329). Studi pustaka adalah metode pengumpulan data dengan mencari informasi lewat buku, majalah, koran, dan literatur lainnya yang bertujuan untuk membentuk sebuah landasan teori (Arikunto, 2016:10).

Analisis data dalam penelitian ini menggunakan bantuan aplikasi Statistical Product Service Solution (SPSS) 16 for Windows. Dimana teknik analisis data yang digunakan terdiri dari, regresi linear sederhana, koefisien korelasi, koefisien determinasi dan uji hipotesis.

\section{Definisi Operasional Variabel}

Definisi operasional dari variabel-variabel yang diteliti dalam penelitian ini yaitu (1) Struktur modal adalah perimbangan antara penggunaan modal sendiri dan modal pinjaman yang digunakan dalam pengelolaan unit usaha dengan menjumlahkan modal sendiri (saham peferen, saham biasa, laba ditahan) dan modal pinjaman PT. Telekomunikasi Indonesia Tbk. (2) Laba merupakan penghasilan perusahan yang diukur berdasarkan perbandingan pendapatan dan biaya.

Tujuan perhitungan laba pada dasarnya memiliki 2 tujuan yaitu :

a. Tujuan internal, yang dimana berhubungan ataupun saling berkaitan dengan manajemen untuk mengarahkan pada kegiatan yang lebih mengevaluasi usaha yang telah dicapai serta lebih menguntungkan.

b. Tujuan eksternal, dimana tujuannya untuk memberikan pertanggungjawaban bagi para pemegang saham guna keperluan pajak ataupun tujuan lainnya.

Jenis-jenis laba yaitu antara lain sebagai berikut:
a. Laba kotor;
b. Laba operasi;
c. Laba bersih;
d. Laba ditahan;
e. Laba per saham.

\section{Analisis Teoritis}

Menurut Oladipupo and Okafor (2012), Debt to Equity Ratio (DER) merupakan alat ukur yang dapat digunakan untuk mengukur Struktur modal. Dimana Debt to Equity Ratio ialah perimbangan total hutang perusahaan dengan total ekutas perusahaan dan satuan pengukuran DER ialah presentase. Dengan rumusnya :

$$
\text { DER }=\frac{\text { Total Hutang }}{\text { Total Ekuitas }} \times 100 \%
$$

Sumber : Oladipupu and Okafor, 2012

Harahap (2015:112), mengatakan 
bahwa laba merupakan sebagian jumlah yang bersumber dari pengurangan harga pokok produksi, biaya lain, serta kerugian dari pendapatan operasi. Sementara menurut Lumbantoruan dan Magdalena (2011:236), laba merupakan selisih antar pendapatan dan biaya. Sedangkan menurut Suwardjono (2008:464) "Laba dimaknai sebagai imbalan atas upaya perusahaan menghasilkan barang dan jasa". Hal ini berarti menyimpulkan adalah kelebihan yang didapatkan setelah dikurangi dengan biaya

(biaya total yang melekat dalam kegiatan produksi dan penyerahan barang/jasa)"

Berdasarkan pendapat para ahli diatas maka peneliti mengambil pengukuran Laba memakai selisih antar pendapatan yang diwujudkan dari transaksi pada periode tertentu dikurangi dengan biaya yang dikeluarkan pada periode yang sama.

\section{Analisis Statistik}

a. Analisis Regresi Linier Sederhana

Regresi linier sedrhana adalah hubungan secara linear antara satu variabel independen (x) dengan variabel dependen (y), analisis ini untuk mengetahui hubungan antar variabel independen dengan variabel dependen apakah positif atau negatif dan untuk memprediksi nilai dari variabel dependen apabila nilai variabel independen mengalami kenaikan atau penurunan. Adapun rumus dari regresi linear sederhana yaitu:

$$
\mathrm{Y}=\mathrm{a}+\mathrm{bx}
$$

Keterangan:

$\mathrm{Y}=$ variabel dependen (nilai yang diprediksikan)

$\mathrm{X}=$ variabel independen

$\mathrm{a}=\operatorname{kosntanta}($ nilai $\mathrm{y}$ apabila $\mathrm{x}=0$ )

$\mathrm{b}=$ koofisien regresi (peningkatan atau penurunan

b. Analisis Koefisien Korelasi
Pengertian analisis korelasi menurut Sarwono (2006:37) adalah Analisis korelasi digunakan untuk melihat kuat lemahnya antara variabel bebas dengan terikat. Koefisien korelasi atau produk moment digunakan untuk mengetahui pengaruh antara dua variabel dinyatakan dalam satu indeks.

Berikut adalah tabel interval untuk mengukur tingkat hubungan antar variabel.

\section{Tabel 2 \\ Interval koefisien Korelasi}

\begin{tabular}{cc}
\hline $\begin{array}{c}\text { Interval Koefisien } \\
\text { Korelasi }\end{array}$ & Tingkat Hubungan \\
\hline $0.00-0.199$ & Sangat Rendah \\
$0.20-0.399$ & Rendah \\
$0.40-0.599$ & Sedang \\
$0.60-0.799$ & Kuat \\
$0.80-1.00$ & Sangat Kuat \\
\hline
\end{tabular}

c. Analisis Koefisien Determinasi $\left(\mathrm{R}^{2}\right)$

Koefisien determinasi adalah salah satu bagian dari analisis regresi linear sederhana yang mana digunakan untuk mengukur kemampuan variabel independen dalam menjelaskan varibel dependen,dengan kata lain, nilai koofisien determinasi menyatakan proporsi keragaman pada variabel bergatung yang mampu dijelaskan oleh variabel penduganya. Nawari (2010:96). Analisis determinasi digunakan untuk mengetahui seberapa besar dampak perubahan variabel $\mathrm{X}$ terhadap variabel Y.

d. Uji t

Priyanto

(2012:139), menjelaskan bahwa Uji $t$ atau uji koefisien regresi secara parsial digunakan untuk mengetahui apakah secara parsial variabel independen berpengaruh secara signifikan atau tidaknya terhadap variabel dependen. Untuk menentukan nilai t-tabel, tingkat signifikan yang digunakan sebesar 5\%. Wijaya (2012:107). 


\section{HASIL DAN PEMBAHASAN}

1. Hasil Analisis Data

a. Uji Regresi Linear Sederhana

Metode ini digunakan untuk menganalisis besarnya hubungan dan pengaruh variabel independenyaitu Strutur Modal (X) terhadap variabel dependen yaitu laba (Y). Persamaan umum regresi sederhana adalah $\mathrm{Y}=\mathrm{a}$ $+\mathrm{bx}$, yang masing-masing komponen $\mathrm{a}$ dan $\mathrm{b}$ diperoleh dengan metode kuadrat terkecil dengan menggunakan program SPSS.

\section{Tabel 3}

\begin{tabular}{|c|c|c|c|c|c|}
\hline \multirow[b]{2}{*}{ Model } & \multicolumn{2}{|c|}{$\begin{array}{l}\text { Unstandardized } \\
\text { Coefficients }\end{array}$} & \multirow{2}{*}{$\frac{\begin{array}{c}\text { Standardized } \\
\text { Coefficients }\end{array}}{\text { Beta }}$} & \multirow[b]{2}{*}{$\mathrm{T}$} & \multirow[b]{2}{*}{ Sig. } \\
\hline & B & Std. Error & & & \\
\hline 1 (Constant) & -29130.671 & 33020.280 & & -.882 & .427 \\
\hline $\begin{array}{l}\text { Struktur } \\
\text { Modal }\end{array}$ & 131475.610 & 79144.901 & .639 & 1.661 & .172 \\
\hline
\end{tabular}

Berdasarkan tabel diatas dapat diperoleh rumus regresi sederhana yaitu :

$$
\begin{aligned}
& Y=a+b X \\
& Y=-29130.671+131475.610 X
\end{aligned}
$$

Adapun interprestasi dari regresi diatas adalah sebagai berikut :

- Konstanta (a)

Nilai konstanta sebesar 29.130,671 rupiah yang berarti jika struktur modal (X) sama dengan nol maka laba (Y) akan menurun sebesar 29130.671 kali.

- Struktur modal (X) Terhadap Laba (Y)

Nilai koefisien struktur modal untuk variabel X sebesar 131.475,610 rupiah dan bertanda positf. Hal ini mengandung arti bahwa setiap kenaikan srtuktur modal satu rupiah maka variabel laba akan naik sebesar 131.475,610 kali begitupun sebaliknya.

b. Uji Koefisien Korelasi
Korelasi merupakan teknik analisis yang termasuk dalam salah satu teknik pengukuran asosiasi / hubungan (measures of association). Untuk melihat pengaruh Struktur Modal terhadap laba maka digunakan analisis korelasi.

\section{Tabel 4}

\section{Hasil Perhitungan Korelasi}

Correlations

\begin{tabular}{llrr}
\hline & & $\begin{array}{c}\text { Struktur } \\
\text { Modal }\end{array}$ & Laba \\
\hline Struktur & Pearson Correlation & 1 & .639 \\
Modal & Sig. (2-tailed) & 6 & .172 \\
& $\mathrm{~N}$ & .639 & 6 \\
\hline Laba & Pearson Correlation & .172 & 6 \\
& Sig. (2-tailed) & 6 & \\
& $\mathrm{~N}$ & Berdasarkan & table correlation
\end{tabular}

diatas, pengaruh variabel Struktur Modal (X) dengan variabel Laba (Y) mempunyai hubungan yang kuat dengan nilai person correlation sebesar 0,639.

c. Koefisien Determinasi

Koefisien Determinasi $\left(R^{2}\right)$ bertujuan mengukur tingkat ketepatan dari regresi linear berganda yaitu persentase sumbangan (goodress of fit) dari variabel bebas terhadap variabel terikat.

\section{Tabel 5}

\section{Hasil Uji Koefisien Determinasi}

\begin{tabular}{|c|c|c|c|c|}
\hline Model & $\mathbf{R}$ & R Square & $\begin{array}{l}\text { Adjusted R } \\
\text { Square }\end{array}$ & $\begin{array}{l}\text { Std. Error of } \\
\text { the Estimate }\end{array}$ \\
\hline 1 & $.639^{a}$ & .408 & .260 & 4137.798 \\
\hline
\end{tabular}

Model Summary

bahwa nilai koefisien determinasi $\left(\mathrm{r}^{2}\right)$, sebesar 0,408 atau sebesar 40,8\% yang artinya struktur modal berpengaruh sebesar 40,8\% terhadap laba dan sisanya 59,2\% dipengaruhi variabel lain yang tidak di ukur dalam penelitian ini.

d. Uji Hipotesis

Untuk melakukan pengujian hipotesis, penulis menggunakan uji $\mathrm{t}$ 
dimana akan dibandingkan antara $\mathrm{t}$ hitung dengan t tabel. Dari data pada tabel 2 diatas diperoleh $t_{\text {hitung }}$ sebesar 1,661 . Untuk menentukan $t_{\text {tabel }}$ dapat dilihat dalam lampiran statistika $t_{\text {tabel }}$ dengan menggunkan $\alpha=5 \%$ atau $0,05: 2$ dengan $\mathrm{df}=\mathrm{n}-\mathrm{k}$ atau $6-2=4$. Maka diperoleh $t_{\text {tabel }}$ sebesar 2,776. Maka dari itu diperoleh nilai thitung $1,661<\mathrm{t}_{\text {tabel }} 2,776$, dan nilai sig 0,172 $>0,05$, maka dapat disimpulkan bahwa variabel Struktur Modal tidak berpengaruh dan tidak signifikan terhadap Laba.

e. Pengaruh Struktur Modal Terhadap Laba

Berdasarkan hasil analisis data diatas Maka dari itu diperoleh nilai $\mathrm{t}_{\text {hitung }} 1,661<\mathrm{t}_{\text {tabel }} 2,776$, dan nilai sig $0,172>0,05$, maka dapat disimpulkan bahwa variabel Struktur Modal tidak berpengaruh dan tidak signifikan terhadap Laba maka dari itu sesuai dengan dasar pengambilan keputusan di atas dapat di simpulkan bahwa $\mathrm{HO}$ diterima dan Ha ditolak.

Hasil penelitian ini mendukung penelitian yang dilakukan oleh Dira dan Astika (2014) yang menyatakan bahwa struktur modal tidak berpengaruh terhadap kualitas laba. Selain itu hasil penelitian berbeda dengan penelitian Astivasari dan Siswanto (2018) yang menyatakan bahwa Struktur modal berpengaruh positif signifikan terhadap profitabilitas.

Berdasarkan hasil analisis yang sudah dilakukan diatas, dapat diketahui bahwa struktur modal berpengaruh tidak signifikan terhadap laba pada PT. Telekomunikasi Indonesia Tbk. Hal ini disebabkan oleh persentase perubahan yang berfluktuasi pada nilai Debt to Equity Ratio (DER) perusahaan. Perubahan nilai DER yang di peroleh justru memberikan dampak yang kurang baik pada laba perusahaan. Adapun faktor lain yang ikut berpengaruh sebagai penyebab tidak adanya pengaruh antar variabel dalam penelitian ini adalah faktor makro ekonomi seperti terjadinya inflasi dan meningkatnya suku bunga. Tingkat suku bunga yang tinggi akan mengakibatkan bertambahnya biaya operasional perusahaan dan secara langsung akan berpengaruh terhadap besarnya kebutuhan modal yang dibutuhkan perusahaan. Hal ini dapat menjelaskan kenapa struktur modal tidak berpengaruh signifikan terhadap laba yang di hasilkan perusahaan. Sebaliknya, apabila tingkat suku bunga rendah akan menyebabkan berkurangnya beban bunga yang harus di bayarkan perusahaan. Beban bunga yang rendah akan membuat biaya operasional perusahaan turun sehingga struktur modal yang digunakan perusahaan sedikit dan perusahaan secara tidak langsung dapat meminimalkan penggunaan modal pinjaman yang telah di pinjam dari pihak ke tiga.

\section{SIMPULAN}

Berdasarkan hasil analisis data diatas Maka dari itu diperoleh nilai $t_{\text {hitung }}$ $1,661<t_{\text {tabel }} 2,776$, dan nilai sig $0,172>$ 0,05, maka dapat disimpulkan bahwa variabel Struktur Modal tidak berpengaruh dan tidak signifikan terhadap Laba maka dari itu sesuai dengan dasar pengambilan keputusan di atas dapat di simpulkan bahwa $\mathrm{HO}$ diterima dan $\mathrm{Ha}$ ditolak. Dengan demikian dapat di artikan bahwa tidak ada pengaruh yang signifikan antara Struktur Modal terhadap Laba.

Peneliti menyadari bahwa penelitian ini masih jauh dari kata sempurna, untuk itu berikut adalah beberapa saran untuk peneliti selanjutnya agar menjadi bahan pertimbangan dalam melakukan penelitian dengan topik penelitian yang sama. Diharapkan penelitian berikutnya bisa lebih teliti dan selektif lagi dalam memikirkan waktu penelitian agar bisa sesuai dengan tema penelitian. Selain itu 
diharapkan penelitian berikutnya bisa menambah variableindependent lainnya yang bisa mendeskripsikan variable dependent, sehingga nilai adjusted $\mathrm{R}^{2}$ akan lebih meningkat, serta penelitian berikutnya sebaiknya menambahkan data sampel yang diteliti. Selanjutnya penelitian berikutnya bisa lebih memanjangkan waktu oservasinya agar distribusi datanya meningkat dan lebih baik. Serta peneliti juga harus mempertimbangkan variable-variable yang kira-kira dapat berpengaruh terhadap struktur modal guna melihat keadaan pasar modal yang sebenarnya, sehingga bisa menghasilkan fakta ataupun informasi yang lebih membantu.

\section{DAFTAR PUSTAKA}

Arikunto, S. 2016. Prosedur Penelitian Suatu Pendekatan Praktik. Jakarta: Rineka Cipta.

Astivasari dan Siswanto.(2018). Pengaruh Struktur Modal Dan Ukuran Perusahaan Terhadap Profitabilitas Perusahaan Indonesia (Studi Pada Perusahaan Sektor Properti Dan Real Estate Yang Listing Di BeiPeriode 2012-2014). EKOBIS - Ekonomi Bisnis. Vol. 23 No. 1.Halaman 35-42

Baridwan, Zaki. (2010). Sistem Akuntansi Penyusunan Prosedur dan Metode. Edisi 5. Yogyakarta : BPPE

Brigham, Houston. 2011.Dasar-dasar Manajemen Keuangan. Salemba Empat: Jakarta

Diradan Astika.(2014). PengaruhStruktur Modal, Likuiditas, Pertumbuhan Laba, Dan Ukuran Perusahaan PadaKualitas Laba. E-Jurnal Akuntansi Universitas Udayana. 7. 1. (2014):64-78

Gitman, L.J. dan Zutter, C.J. (2012). Principles of Managerial Finance. Thirteenth Edition. United States: Prentice Hall
Halim dan Sarwoko. (2008). Manajemen Keuangan (dasar-dasar pembelajaran perusahaan). BPFE. Yogyakarta.

Harahap, Sofyan Syafri. 2015. AnalisaKritis atas Laporan Keuangan. Jakarta: PT Raja Grafindo Persada.

Lumbantoruan, Magdalena. 2003. Ensiklopedia Ekonomi, Bisnis, dan Manajemen, Cetakan kedua. Jakarta: PT. Delta Pamungkas.

Martono. (2004). Manajemen Keuangan, Ekonisia. Yogyakarta.

Nafarin. (2007). Penganggaran Perusahaan. Edisi 3. Jakarta: Salemba Empat.

Nawari. 2010. Analisis Regresi Dengan MS Excel 2007 dan SPSS 17. Jakarta: PT. Elex Media Komputindo.

NovitadanSofie.(2015). Pengaruh Struktur Modal Dan Likuiditas Terhadap Profitabilitas.e-Journal Akuntansi Trisakti. Volume.2 Nomor. 1. Hal. 13-18.

Oladipupo, A.O and Okafor, C.A. (2012). Relative Contribution of Working Capital Management to Corporate Profitability and Dividend PayoutRatio : Evidence from Nigeria. International Journal of Business and Finance Management Research, 1: pp: 11-20.

Priyanto. 2012. Belajar Cepat Olah Data Statistik Dengan SPSS. Yogyakarta: Cv Andi Offest

Sartono, Agus. (2010). Manajemen Keuangan, Teori dan Aplikasi. Yogyakarta : BPFE

Sugiono. 2015. Metode Penelitian Kombinasi (Mix Methods). Bandung :alfabeta

Sugiono (2016). Metode Penelitian Kuantitatifdan $R \& D$. Bandung : PT Alfabet.

Suwardjono. 2008. Teori Akuntansi Perekayasaan Pelaporan Keuangan. Yogyakarta : BPFE 
Weston, J.Fred, and Thomas E. Copeland.(2002). Manajerial Finance. Eight Edition, Dryden Press. 